\title{
低真空中でのレーザ生成プラズマおよびレーザトリガ放電の基礎特性
}

$\begin{array}{llll}\text { 学生員 大橋 敦 } & \text { (名古屋大学) } \\ \text { 学生員 山納 康 } & \text { (名古屋大学) } \\ \text { 正 員 加藤 克巳 } & \text { (名古屋大学) } \\ \text { 正 員 大久保 仁 } & \text { (名古屋大学) }\end{array}$

\section{Characteristics of Laser-induced Plasma and Laser-triggered Discharge in Low Vacuum}

Atsushi Ohashi, Student Member, Yasushi Yamano, Student Member, Katsumi Kato, Member, Hitoshi Okubo, Member (Nagoya University)

In space vacuum, severe conditions like electron beam irradiation may influence charging and discharging phenomena on surface of space-apparatus. In addition, outgassing from the surface of space apparatus raises local gas pressure around the surface of the apparatus. The outgassing would seriously affect on discharging processes on dielectric surface and thus the quantitative evaluation of outgassing characteristics might be very important. Having with the application to the measurement of local gas pressure in mind, in this paper, we describe the fundamental characteristics of TEA-CO laser-induced plasma and laser-triggered discharge. Especially under low vacuum, we measured laser-induced plasma light intensity, rise/fall time of its waveform in free space or on surface of solid materials like PMMA. We also measured laser-triggered discharge characteristics such as discharge probability, discharge current as a function of vacuum pressure. As a result, we could clarify the pressure dependence of these characteristics. These results may be useful data for the quantitative evaluation of local pressure on solid material in vacuum.

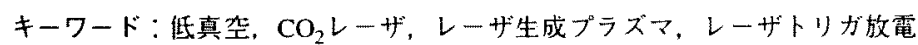

\section{1.まえがき}

宇宙ステーションやスペースシャトルの飛翔する低地球 軌道は高真烲領域にあるが(1-3)，宇宙機の表面においては 荷電粒子の衝突などによって気体放出が起こり，局所的に 圧力の高い部分が存在する。気体放出は，機器表面に付着 した水分の放出, 表面材料中に存在する水素の放出, 蒸気 圧の高い絶縁物や潤滑液体の蒸発が主な原因である(4)。 の気体放出で宇宙機表面は気体の層を形成し，絶縁物表面 上において放電を起こす要因となる。また，宇宙空間に存 在するプラズマやイオンの付着およびX線などの衝突によっ て宇宙機表面に带電が生成されることが報告されてい る ${ }^{(5-6)}$ 。このような帯電・放電現象によって絶縁物が劣化 したり，宇宙機内部の電子機器が故障することが報告され ている(7。しかしながら，気体放出と带電・放電の相互作 用はいまだ研究段階であり，詳細は未解明である。将来宇 宙開発を進めるにあたり，宇宙空間における高電圧適用を 考慮した宇宙機の信頼性の向上のためには，真空中におけ るこれらの相互関係を明らかにし，その抑制技術を確立す る必要がある。また, 現在, 宇宙機における帯電・放電に 関するガス放出や局所ガス ${ }^{(8)}$ あいは低真空中の部分放電 現象 ${ }^{(9)}$ が注目を集めている。
筆者らは，レーザトリガ技術(16-11)を応用し，宇宙環境に おける気体放出と鱼電・放電現象の関係を明らかにし，そ の防止技術拈よび絶縁技術の確立を目的として研究を進め ている (12-13)。局所圧力の定量的測定を最終的な最終目標と する中，本研究ではその前段階として，真空中におけるレー ザ生成ブラズマおよびそのプラズマによって誘起された放 電(以後レーザトリガ放電と呼ぶ)の圧力特性の測定を行っ ている。今回、レーザ生成プラズマ発光の基脴的特性の取 得のため低真空領域に扮いてこれらの压力特性の測定を行っ た。この結果，圧力の低下に伴いレーザ生成プラズマ領域 は拡大し，また，生力の低下および印加電生の上昇によっ てレーザトリガ放電電流が増加するなど，レーザ生成プラ ズマおよびレーザトリガ放電の諸特性を明らかにしたので 報告する。

\section{2. 実験装置}

実験装置を Fig.1 に示す。ステンレス(SUS-304)製の真空 容器は直径 $250 \mathrm{~mm}$, 高さ $200 \mathrm{~mm}$ の円筒形をしており, 内 容積は䄪10にである。レーザ光を導入するためZnSe製の空 (直径 $70 \mathrm{~mm}$, 厚さ $6 \mathrm{~mm}$ )を設置し,この容器を $10^{3} \mathrm{~Pa}$ 台まで 排気した。 


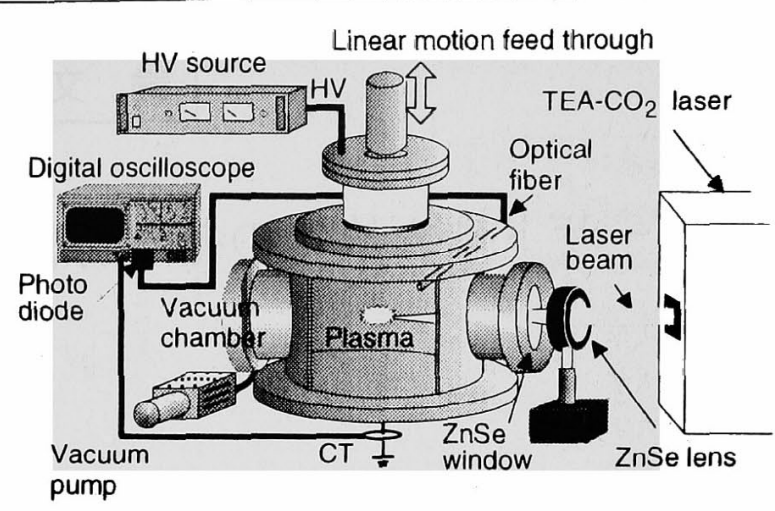

図 1 実験装置

Fig.1 Experimental setup.

本研究ではブラズマを生成するにあたって，高効率・高 出力の代表的赤外域分子レーザであるTEA (Transversely Excited Atmospheric pressure)-CO2パルスレーザを使用した。 Table1に本研究で使用したレーザの仕様を示す。このレー ザは波長10.6umであり，一回の照射における最大エネルギー は4.2Jである。

このような特性を有するレーザ光を焦点距離 $\mathrm{f}=200 \mathrm{~mm} の$

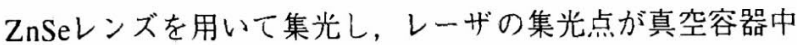
心付近に来るようにZnSeレンズおよび真空容器の位置を設 定した。このようにして自由空間および集光点上に設置さ れた各種固体ターゲット上にレーザ生成プラズマを発生さ せた。

さらに、レーザトリガ放電の実験を行うにあたり，Fig.2 に示す 2 種類の電極系を用いた。Fig.2 (a)の平行平板電極

\section{表 1 TEA-CO 2 レーザ特性}

Table I Specifications of TEA-CO $\mathrm{CO}_{2}$ laser.

\begin{tabular}{|c|c|}
\hline Wavelength & $10.6 \mu \mathrm{m}$ \\
\hline Maximum energy & $4.2 \mathrm{~J}$ \\
\hline Pulse width & $100 \mathrm{nsec}$ \\
\hline Power stability & $\pm 2 \%$ \\
\hline Beam size & $30 \mathrm{~mm} \times 30 \mathrm{~mm}$ \\
\hline
\end{tabular}

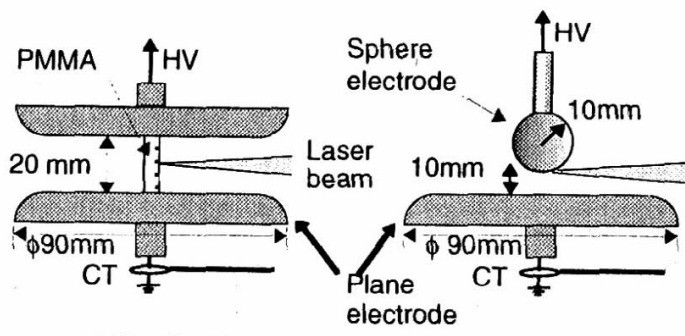

(a) 平行平板電極

(a) Parallel-plane electrodes

(b) 球平板電極

(b) Sphere-plane electrodes

\section{図2 実験に用いた電極系}

Fig.2 Electrode configurations for measuring plasma production and laser-triggered discharge.
のギャッブ長を $20 \mathrm{~mm}$ とし、ギャッブ間に挟んだPMMA上 にレーザを集光した。なお，ステンレス(SUS-304)製の平 板電極は直径 $90 \mathrm{~mm}$ で端部は $\mathrm{r}=10 \mathrm{~mm}$ の電界緩和がなされて いる。Fig.2 (b) の球平板電極はギャップ長を $10 \mathrm{~mm}$, 上部 球電極の半径を $10 \mathrm{~mm}$ とし, 平板電極はFig.2 (a) と同一と した。また本電極系では, レーザ光を球電極先端に集光し た。この両電極系の上部電極には10M $\Omega$ の保護抵抗を介し, 正極性直流電圧 $(0 ２ 0 \mathrm{kV})$ を印加 $し$, 下部電極は電流導人 端子およびCTを介して接地した。このようにしてレーザ を集光することでレーザ生成プラズマによるトリガ放電を 誘起した。

プラズマ発光観測は，フォトダイオード(波長範囲：190 $\sim 1000 \mathrm{~nm}$, 応答速度 $0.1 \mu \mathrm{s})$ およひ静止カメラで行った。フォ トダイオードではプラズマ発光強度を測定しており，レー ザからのノイズ対策のために，光ファイバの先端を真空容 器中に導入し，プラズマ光を長さ $8 \mathrm{~m} の$ 光ファイバでフォ トダイオードまで導いた。な扔，発光観測系の応答速度は $0.2 \mu \mathrm{s}$ である。また，レーザトリガ放電電流の測定はCT(応 答速度：0.5ns)を用いて行った。静止カメラによるプラズ マ発光測定はレーザ照射よりプラズマ生成終了まで開放す ることで撮影した。

本研究においては $0.8 \mathrm{kPa} \sim 0.1 \mathrm{MPa}$ の圧力範囲で，実験を 行った。なお，実験環境は気温 $20^{\circ} \mathrm{C}$, 湿度 $30 \%$ とした。

\section{3. プラズマ生成のレーザエネルギー依存性}

レーザエネルギーおよび圧力を変化させてプラズマ生成 確率を求めた。なお，生成確率は100回レーザを照射した ときのプラズマ生成回数で定義した。はじめに, 自由空間

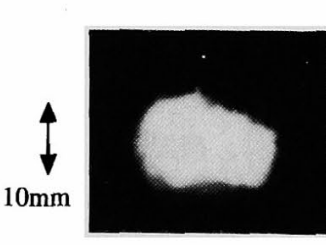

(a) $0.1 \mathrm{MPa}, \mathrm{E}=3.9 \mathrm{~J}$
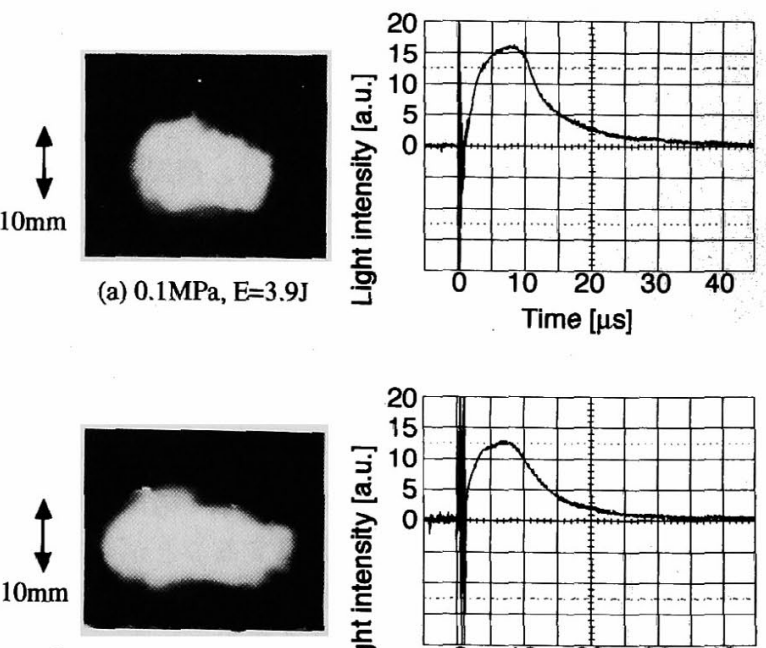

(b) $53 \mathrm{kPa}, \mathrm{E}=3.6 \mathrm{~J}$

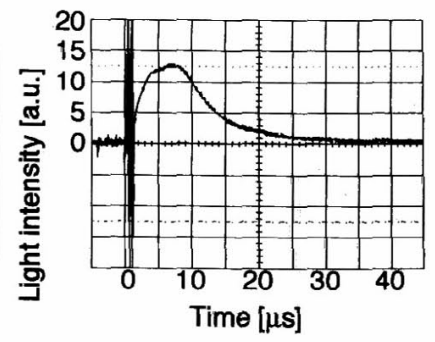

図 3 自由空間におけるレーザ生成プラズマ発光像およ びプラズマ発光波形

Fig.3 Laser-induced plasma light image and light intensity waveform in free space in low vacuum. 
に拈いてレーザ生成プラズマの測定を行った。このときの レーザ生成ブラズマの発光像および発光波形を Fig. 3 に示 す。本論文においては可視光を発する領域をレーザ生成ブ ラズマと定義している。同一条件において，レーザ生成ブ ラズマの生成位置にはばらつきが見られるものの，大きさ， 発光色等はほぼ同様であることを確認した。Fig. 4 にレー ザ照射エネルギーとプラズマ生成確率の関係を示す。なお， レーザエネルギーは1.6－3.9J, 圧力は $27 \mathrm{kPa} 〜 0.1 \mathrm{MPa} と し$ た。同図から，レーザ照射エネルギーか增加するにつ机て， また压力が上昇するにつ机て，レーザ生成プラズマの生成 確率は高くなっていることがわかる。これは，レーザエネ ルギーの増加によって注入エネルギーが増加し, また压力 の上舁によってプラズマの核となる気中分子が増加するた め,これらの相互作用でブラズマ生成確率が高くなったも のと考えられる。

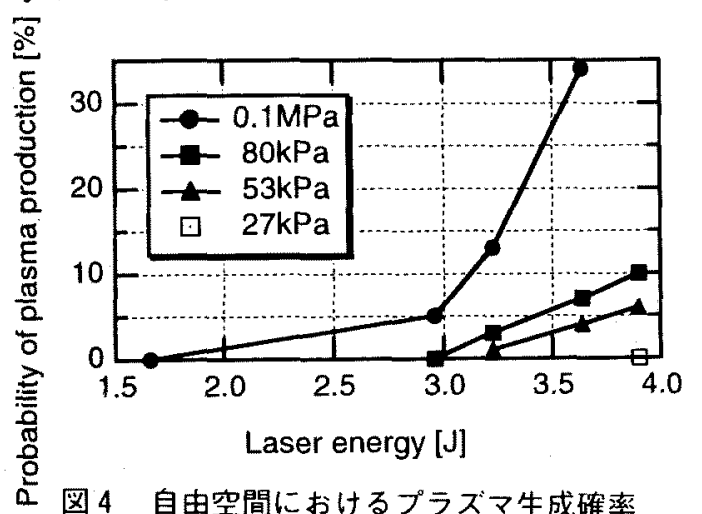

Fig.4 Probability of laser-induced plasma production.

\section{4.レーザ生成プラズマ発光の圧力依存性}

次にレーザ光をPMMA, SUS-304, $\mathrm{Al}_{2} \mathrm{O}_{3}$ の各種固体試料 に集光し，压力を $0.8 \mathrm{kPa}-0.1 \mathrm{MPa}$ に変化させてレーザ生成 プラズマを発生させた。なお、レーザエネルギーは3.2Jと 一定にした。雲囲気の一様化を図るため、レーザの照射間 隔は 3 分としてプラズマ生成確率および発光強度等の測定 を行った。今回, ターゲット材料としては代表的絶縁物で あるPMMAや構造材料のステンレス(SUS-304)を用いた。 以下に測定結果を示す。

Fig. 5 にPMMAおよびSUS-304に3.2J一定としたレーザを 集光したときのプラズマ発光像の圧力变化を示す。同図よ り, 圧力が低下するに従い発光領域が拡大し, 発光強度は 低下することがわかる。これは，圧力の低下により平均自 由行程が増加することでプラズマが拡散しやすくなる結果, プラズマ領域が拡大し，プラズマ密度が低下したと考えら れる。また, 発光色は压力が低下するに従い, 淡青色から 赤紫色(PMMA) もしくは青白色(SUS-304, $\mathrm{Al}_{2} \mathrm{O}_{3}$ )に変化す ることを確認した。これは圧力の違いによってプラズマ密 度が簧なること，あるいは，プラズマ化する分子が異なっ ていることが影響しているものと考えられる。すなわち， 高い圧力領域においては空気の成分である $\mathrm{N}_{2}, \mathrm{O}_{2}$ 等が主と
してフラズマ化しているのに刘し，低い圧力領域に执いて はプラズマ化する成分がPMMAやSUS-304などの固体夕ー ゲットに依存していると考えられる。また，各試料とも圧 カ1 - $2 \mathrm{kPa}$ 以下の領域になると急激に発光が微弱になるこ とがわかり，ブラズマ化する成分が急に变化する閾值の存 在が示昖された。

Fig. 6 に上述のプラズマ発光に扔ける発光強度波形を示 す。同図より圧力の低下によりプラズマ発光强度は低下し ていることがわかる。これは，先述したとおりプラズマ密 度が低下したため発光が希薄になったと考えられる。また， 発光の立ち上がり約师をみてみると，どの圧力において も同様の傾きを示していることがわかる。以上のことから， 発光開始から1 $\mu \mathrm{s}$ までのプラズマ発光は夕ーゲット材料の プラズマ化に，14s以降に拈ける発光は気中分子のプラズ マ化に起因していると考えられる。そのため圧力の低下に より，発光強度に差が生じる。

Fig.7に各圧力における各試料上にレーザを集光したと きのレーザ生成プラズマ発光強度のピータ值の圧力依存性 を示す。この図より発光のピークは圧力の低下にしたがっ て徐々に減少していくことがわかる。しかしながら，今回 実験を行った低真空領域においては，ターゲット材料はプ ラズマ発光のピークにほとんど影響を与えないことがわか る。これは, Fig. 6 で発光の俊期に気中分子のプラズマ化 によるピークが生じることからも妥当であると考えられる。 さらに低い圧力領域でのプラズマ発光を考えると, 発光の ピークはターゲット材料に依存する上うになることが Fig. 6 の発光波形よりうかがえる。なお，ブラズマ発光に おいて立ち上がりおよび立ち下がり時間が压力の低下に伴 い減少していくことを確認している。

Fig. 5 から，压力の低下によってブラズマ発光領域が拡 大し，その後，縮小することがわかる。そこで，プラズマ 発光の定量化を图るため発光領域の大きさを各圧力でまと めた。Fig. 8 にレーザをPMMAに集光したときのプラズマ 発光の横方向の広がりを各圧力に対して示す。同図より, レーザ生成ブラズマの大きさは，ばらつきはあるものの圧 力が低くなるにつれ大きくなる傾问があることがわかる。 このような変化をするのは，压力の低下により平均自由行 程が増加するため, 全体的にプラズマ領域の大きさが拡大 するためと考えられる。また，この大きさの違いはターゲッ ト溶発によるジェットの噴出が大きく関与しているものと 考えられる。

\section{5.レーザトリガ放電の圧力依存性}

Fig. 2 の電極系において, 電極間に電在を印加した状態 でターゲットにレーザを集光し, 発生したレーザプラズマ によるレーザトリガ放電を誘起した。このときのプラズマ 発光およびトりガ放電電流を測定した。なお、レーザエネ

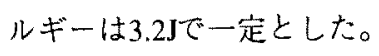



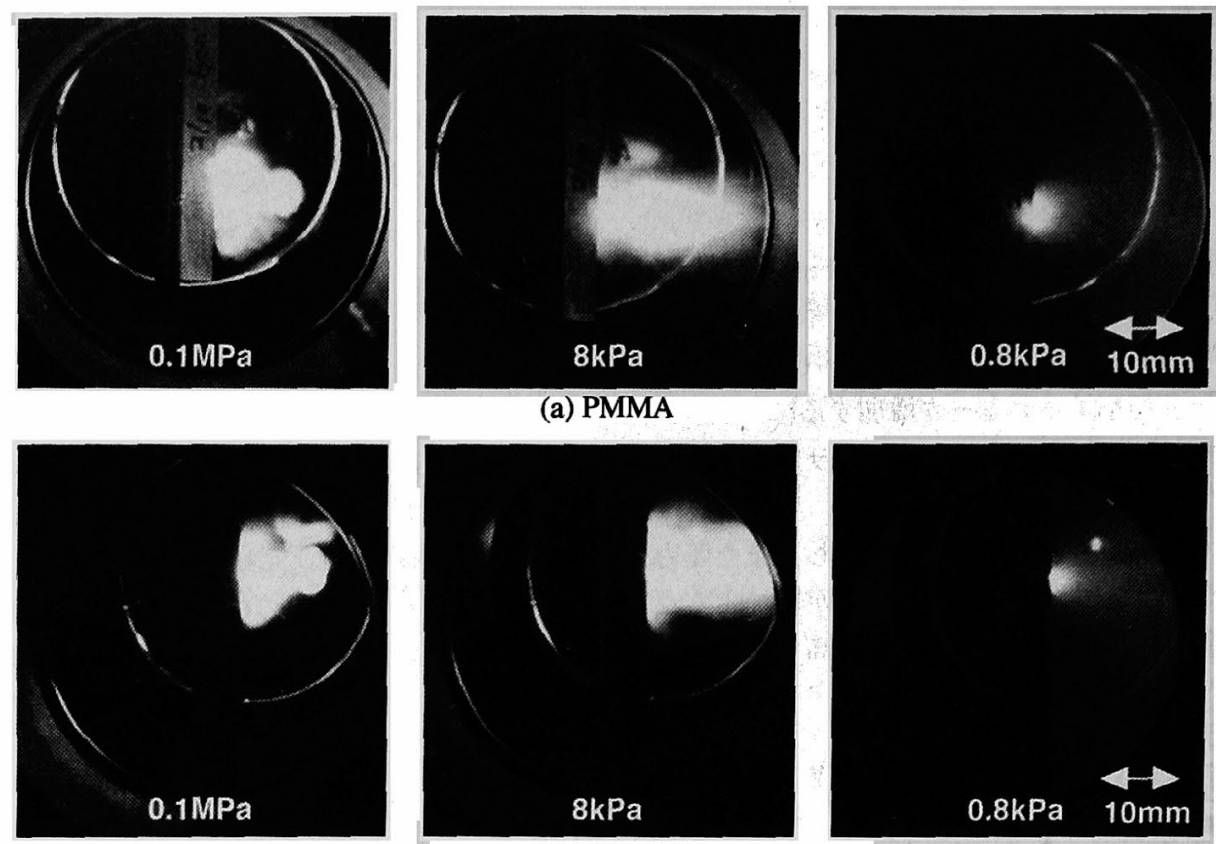

(b) SUS-304

図 5 各種試料にレーザ照射したときのプラズマ発光像

Fig.5 Laser-induced plasma images on various materials at different pressures in vacuum.

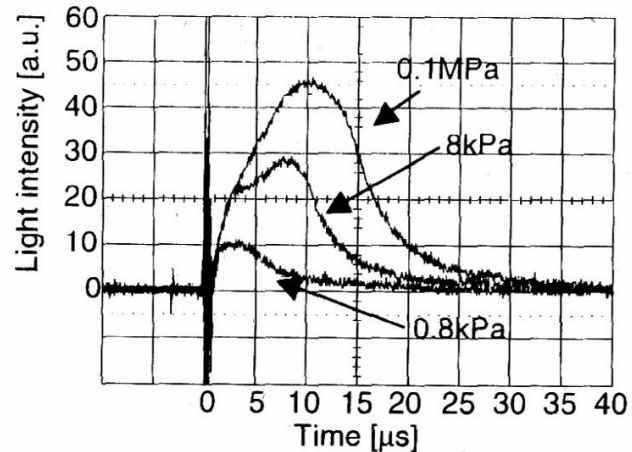

(a) PMMA

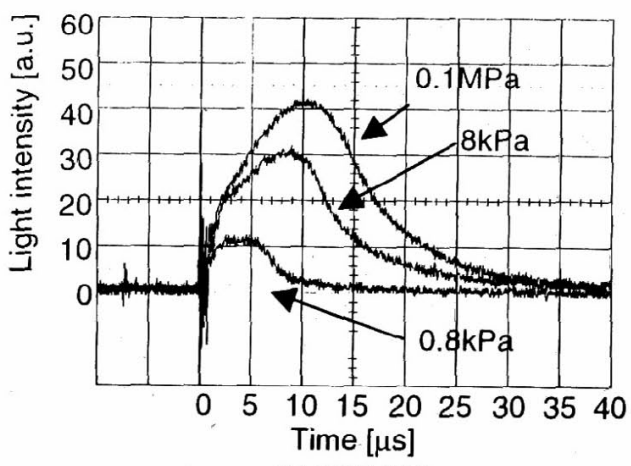

(b) SUS-304

図 6 各種試料にレーザ照射したときのプラズマ発光波形

Fig.6 Waveforms of light intensity of plasma on various materials.

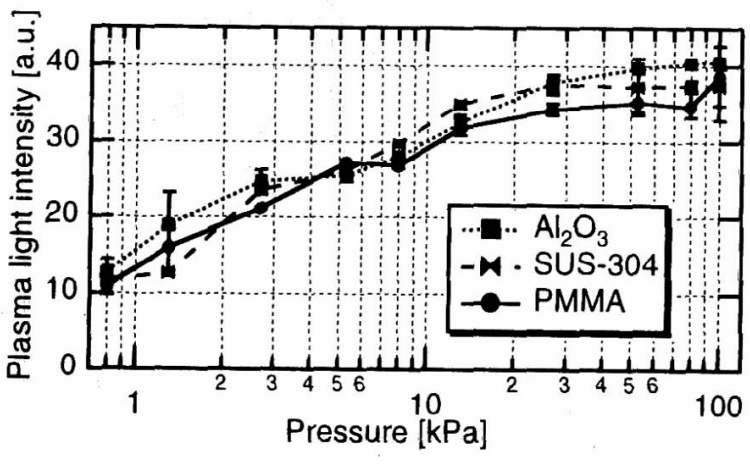

図 7 各種試料にレーザ照射したときのプラズマ発光強 度の圧力依存性

Fig.7 Light intensity of laser-induced plasma.

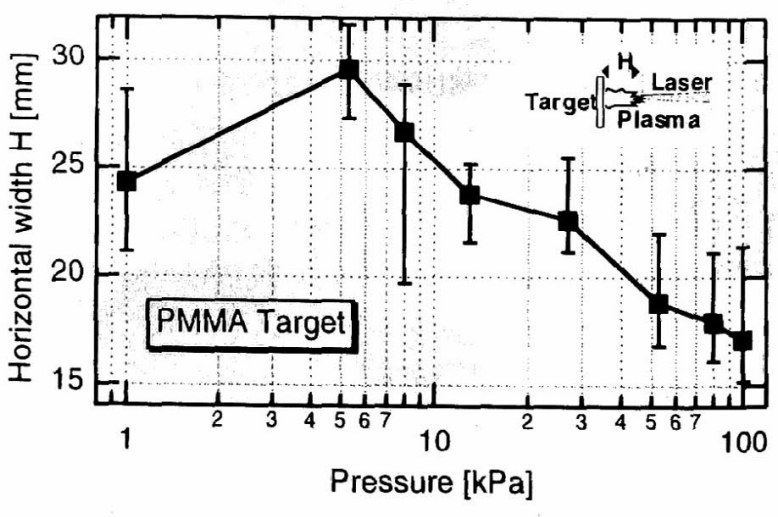

図 8 各圧力下のレーザ生成プラズマの大きさ

Fig.8 Horizontal width $\mathrm{H}$ of laser-induced plasma. 
(a)レーザトリガ放電確率

はじめにFig. 2 (a) の電極系を用いて各圧力における印 加電圧に対するトリガ放電確率を測定した。こ机より，放 電開始電王の閾值が存在し, 圧力が低くなるに栟いその值 が低下することを確認した。トリガ放電電圧を定量化する ため, $100 \mathrm{~mA}$ 以上の放電電流が流机た時点の印加電压を放 電開始電圧とし，放電確率が50\%となったときの印加電圧 を50\%トリガ放電開始電圧と定義した。レーザトリガ放電 開始電压の压力依存性を Fig. 9 に示す。同図より，ギャッ プ長を一定 $(\mathrm{d}=20 \mathrm{~mm})$ としたときのパッシェン曲線(1)と比 較して50\%トリガ放電電圧の傾きが1/5程度になっているこ とがわかる。このように放電開始電圧が低下した原因はプ ラズマ生成によって導電性の領域が形成されたため，実質 的にギャップ間の電界強度が高まったためと考えられる。

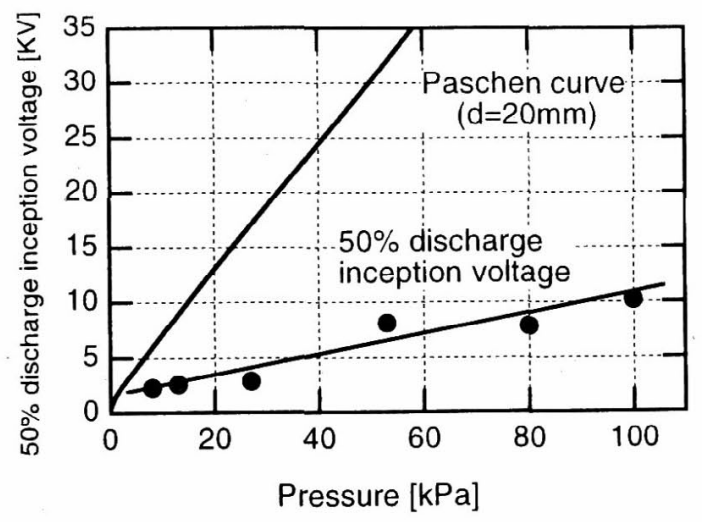

図 9 レーザトリガ放電の $50 \%$ 放電開始電圧

Fig.9 50\% discharge inception voltage triggered by laserinduced plasma as a function of pressure.

(b)レーザトリガ放電電流波形の検討

圧力 $100 \mathrm{kPa}$ よび53kPaにおけるレーザトリガ放電時の プラズマ発光像および発光強度波形, トリガ放電電流波形 を Fig.10に示す。同図に示す発光像においてプラズマは球 電極を包むように拡散し，それぞ机発光形態は若干異なる が電極間を短絡する微弱な放電路が確認された。トリガ放 電は, レーザ照射後 $0.7 \mu \mathrm{s} \sim 0.8 \mu \mathrm{s}$ のプラズマ発光の立ち上 がり初期段階で発生し、はじめプラズマのドリフトによる と考えられる電流が約 $0.5 \mu$ 流れた後, 絶縁破壇と考えら れる急峻な電流が約0.1 1 s 間流れた。プラズマ生成開始 直後に放電が発生したこよからターゲット材料の熔解によ り生じたプラズマがトリガ放電を誘起したのであると考え ている。トリガ放電は電流制限によって減少するが，プラ ズマ発光はその後も増加し，ピークに達する。この現象は 大気圧だけでなく, 真空中においても同様の特性を示した。 また,この時の放電開始電圧は, 最も小さいもので静的な

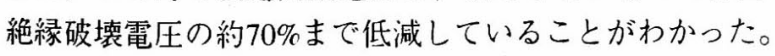

Fig.11に1kPa～53kPaの圧力における印加電圧に対する トリガ放電電流波高值の変化を示す。同図より圧力が低下 するにつれてある印加電圧に対するトリガ放電電流が増加 する特性を示した。このような現象が見られる原因として は，圧力が低下したことで導電性のレーザ生成プラズマ領 域が拡大することから，放電が起こりやすくなったことが あげられる。

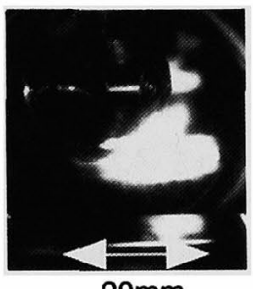

$20 \mathrm{~mm}$

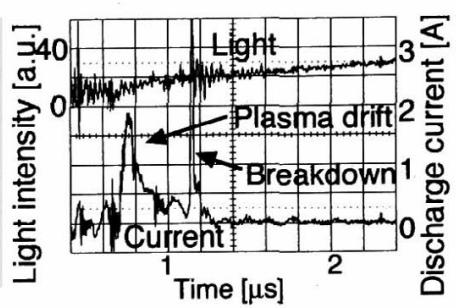

(a) $0.1 \mathrm{MPa}, 20 \mathrm{kV}$

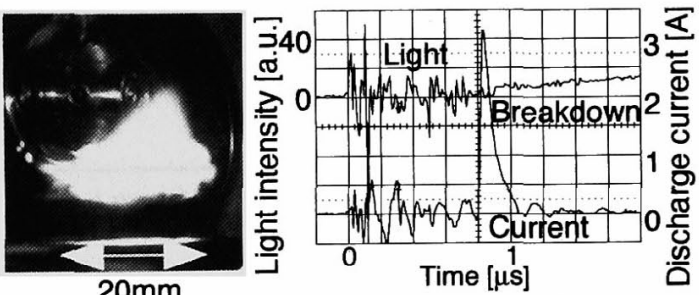

(b) $53 \mathrm{kPa}, 14 \mathrm{kV}$
図10 レーザトリガ放電時のプラズマ発光像および発 光 ・放電電流波形

Fig.10 Image of plasma and waveforms of light intensity and discharge current.

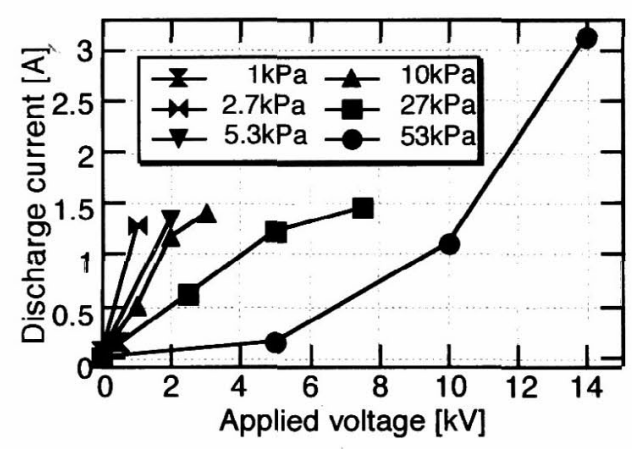

図11 各圧力における印加電圧に対するトリガ放電電流

Fig.11 Laser-triggered discharge as a function of applied voltage at different pressure.

\section{6. まとめ}

本研究では，低真空中において $\mathrm{CO}_{2}$ パルスレーザを用い てレーザ生成プラズマおよびレーザトリガ放電の基礎特性 の取得を行い，以下のことを明らかにした。 
（1）プラズマ生成確率は，レーザエネルギーの増 加书よび圧力の上昇に伴って高くなる。

（2）レーザ生成ブラズマは圧力の低下により発光領域が 拡大し，発光強度が弱くなる特性を示す。

（3）プラズマ発光は立ち上がり約 $1 \mu \mathrm{s} \sim 10 \mu \mathrm{s}$, 波尾約 $10 \mu \mathrm{s}$ の波形を示し，ターゲット材料および気中分子のプ ラズマ発光が重称合ったものと考えている。

(4) プラズマ発光はターゲット材料および気中分子のプ ラズマ化の双方に起因している。

（5）レーザプラズマによって静的な破壊電圧より低い印 加電圧でトリガ放電が誘起され，圧力が高いほど破 壊電圧の低下率が大きくなる。

（6）レーザトリガ放電電流は，圧力の低下および印加電 圧の上昇に従って増加する。

以上のことは, 宇宙機器表面における気体放出に伴う帯 電・放電現象の解明に貢献寸るものと思われる。

(平成 10 年 5 月 25 日受付, 平成 10 年 11 月 5 日再受付)

文献

(1) M. F. Rose: "Power Technology for Space Systems", 6th ISH, 45.01, 1989.

(2) H. M. Banford, M. J. Given and D. J. Tedford: "A Space Simulation of High Voltage Breakdown in Space Power Insulation", IEEE Int. Symp. on Elect. Insul., pp. 24-27, 1992.

(3) L. S. Belyaev, A. S. Koroteev and Y. N. Rudenko : "Power from Space: Expected Role and Influence on Energy System Development", Space Power, Vol.12, No.3\&4, pp.133-142, 1993.

(4) A. C. Logue and L. B. Gordon : "Vacuum Chamber Simulation of High Voltage Breakdown in Space", Proc. of 16th ISDEIV, pp.444-447, 1994.

(5) 藤井, 西本：「人工衛星の带電放電現象」, 静電気 学会誌, Vol.13, No.3, pp.172-181, 1989.

(6) Tumiran, M. Maeyama, H. Imada, S. Kobayashi and Y. Saito : "Flashover from Surface Charge Distribution on Alumina Insulators in Vacuum", IEEE Trans. on Elect. Insul., Vol.4, No.4, pp.400-406, 1991.

(7) H. C. Miller: "Electrical Discharge in Vacuum 1980-1990", IEEE Trans. on Elect. Insul., Vol.26, No.5, pp.949-1043, 1991.

(8) A. R. Frederickson : "Upset Related to Spacecraft Charging", IEEE Trans. on Nuclear Science, Vol.43, No.2, pp.426-441, 1991.

(9) W. G. Dunbar, D. L. Schweickart, J. C. Horwath and L. C. Walko: "High Frequency Breakdown Characteristics of Various Electrode Geometries in Air", Proc. of the 23rd International Power Modulator Symposium, 1998.

(10) 新藤, 三木, 和田, 相原：「レーザ伝搬に伴うプラ
ズマ生成のシミュレーション」, 電気学会論文誌 A,Vol.115, No.7, pp.589-594, 1995.

(11) U. Ghera, R. L. Boxman, H. Kleinman and S. Ruschin: "Laser-induced electron source in a vacuum diode", J. Applied. Phys. 66, pp.4425-4430, 1989.

(12) H. Okubo, S. Yuasa, K. Ota, N. Hayakawa and M. Hikita: "Discharge Characteristics under Non-uniform Electric Field in $\mathrm{He}, \mathrm{Ar}$ and Air at Low Pressures", IEEE Trans. on Elect. Insul., Vol.4, No.4, pp.450-455, 1991.

(13) H. Okubo, K. Ota, S. Yuasa, N. Hayakawa and M. Hikita: "Laser-triggered Discharge Characteristics in Low Vacuum with Residual Gas and Air", Proc. of 17th ISDEIV, pp.683687, 1996.

(14) 宅間, 柳父: 「高電圧大電流工学」, 電気学会, pp.49-50, 1995.

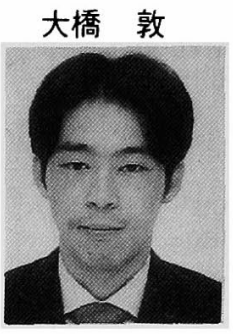

（学生員）1974年10月13日生ま机。97年3 月名古屋大学工学部電気学科卒業。同年4月 同大学大学院工学研究科博士課程前期課程 進学，現在に至る。真空中に扮ける絶縁物 帯電およびレーザトリガ放電に関する研究 に徉事。

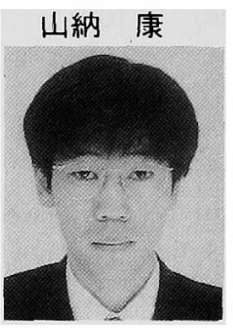

（学生員）1970年6月16日生まれ。96年3月 名古屋工業大学大学院工学研究科博士課程 前期課 程修了。同年4月(株)三菱重工業入社。 98 年名古屋大学大学院工学研究科博士課程 後期課程入学, 現在に至る。真空中におけ る带電・放電に関する研究に従事。

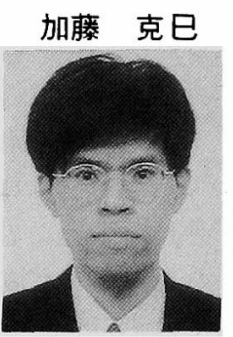

（正員）1969年5月 20 日生まれ。97年3月名古 屋大学大学院工学研究科博士課程後期課程修 了。同年4月同大学助手, 現在に至る。工学博 士。主として, 高電圧機器を対象とした電界 解析技術および電界最適化に関する研究に従 事。96年電気学会進歩賞受賞。

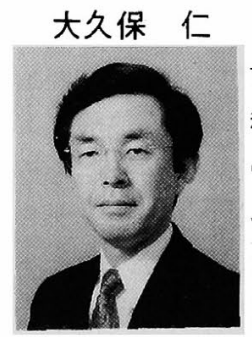

（正員）1948年10月29日生まれ。73年3月名 古屋大学大学院工学研究科博士課程前期課 程修了。同年4月(株)東芝入社。高電圧技術 開発に従事。76年7月 78 年2月ドイッ・アー ヘン工科大学高電圧研究所およびミュンへ ン工科大学高電圧研究所客員研究員。8 9 年 7 月名古屋大学工学部電気学科助教授, 91 年4 月同教授, 現在に至る。工学博士。IEEE, VDE会員。 